\title{
Antimicrobial Activity of Clerodendrum Volubile (Marugbo) Leaves against Selected Microbial Pathogens
}

\author{
Adeyemo I. A ${ }^{1^{*}}$, Omobolade O. ${ }^{2}$ \\ ${ }^{1}$ Department of Biological Sciences, Olusegun Agagu State University of Science and Technology, Okitipupa, Ondo State, Nigeria \\ ${ }^{2}$ Department of Medical Microbiology and Parasitology, College of Medicine, University of Ibadan, Oyo State, Nigeria. \\ *Corresponding author \\ DOI: https://dx.doi.org/10.51584/IJRIAS.2021.6407
}

\begin{abstract}
Oral and written reports from time immemorial revealed that humans have used various plants and plant parts as efficient medicine to treat various ailments. Qualitative phytochemical screening was carried out on extracts of Clerodendrum volubile leaves using ethanol, hot water and cold water as solvents for extraction. The antimicrobial activity of the plant extract was tested against selected human pathogens and was evaluated by agar well diffusion method. Ethanol extracts exhibit higher solubility for more active antimicrobial and phytochemical constituents, consequently displaying the highest antimicrobial activity followed by hot water and least in cold water. The result of this research also established the distribution of various phytochemical constituents in the extracts of Clerodendrum volubile leaves and demonstrates the clinical efficacy of Clerodendrum volubile leaves against the tested pathogens.
\end{abstract}

Keywords: Clerodendrum volubile leaves, antimicrobial activity, phytochemical constituents, extracts.

\section{INTRODUCTION}

$\mathrm{P}$ lants over the years have been constantly used for medicinal purposes, and have been used as food and raw materials for making cloth (Ryszard, 1998). According to The World Health Organization (2002), more than $80 \%$ of the worldwide population relies on the use of traditional medicine to cure several diseases and over $50 \%$ of contemporary drugs are derived from medicinal plants. It has also been estimated that only $17 \%$ of approximately 250,000 medicinal plants species found in every area of the world have been scientifically studied and examined for their medicinal properties and the biological and chemical diversity of these plants could serve as an important sources of new pharmaceuticals (Mamedov, 2012). Medicinal plant-based antimicrobials for the treatment of UTIs are a vast source of potential medications, such as the Asteraceae family, which comprises nearly 1,600 genera and 23,000 species (ChiavariFrederico et.al. 2020; Bessada et.al, 2015)

One of the paramount interests of scientists, who are searching for new drugs with an aim of obtaining greater effective treatment for several diseases, has been screening of plant extracts (Farnsworth, 1988). It has been established that one of the essential requirements in discovery and development of effective pharmaceutical agents involves screening of medicinal sources including plants and other natural products for bioactive components that will yield desirable therapeutic efficacy against diseases plighting human generation for decades (Surendra et.al., 2016). This is necessary because there is a continuous and urgent need to discover new anti-oxidant, anti-tumor, anti-inflammatory and antimicrobial compounds with diverse chemical structures and novel mechanisms of action due to an alarming rise in the incidence of new and re-emerging infectious diseases and development of resistance to the drugs in current clinical use. Actually, most of the known drugs were originally obtained from plants. Importantly, an inverse correlation has been reported between occurrence of some diseases (such as cardiovascular, neurodegenerative diseases, etc.) and the consumption of medicinal plants, vegetables and spices. The active ingredients in plants are the phyto-chemicals; primary or secondary metabolites which possess pharmacological attributes and can alter human physiological processes (Zaria, 2020). Primary metabolites include carbohydrates, proteins and lipids which are essential directly for plant growth and metabolism while secondary metabolites include sterol, flavonoids, alkaloid, phenol, terpene, tannins, essential oil and lignin which not required for metabolic activity. The secondary metabolites are products of primary metabolism. The beneficial effects of Phyto-constituents found in medicinal plants cannot be over-emphasized (Rotimi et.al., 2019)

Medicinal plants are known to possess bioactive compounds having biological activities which can provide therapeutic effects in man. Perhaps, this also contribute to the reason why about $80 \%$ population of the people in developing countries, including Nigeria, still depend on crude herbal remedies in management of ailments such as fever, inflammation, diabetes, cardiovascular diseases and cancer. To the local traditional healers, herbs, medicinal plants and spices remain the principal sources in supply of therapeutic agents including antioxidant compounds. Often, concoctions made via the use of herbs are used for prevention of numerous diseases that are common among the people living in rural areas of developing nations. Therefore, it is paramount to screen medicinal plant 
extracts for their active ingredients and phyto-constituents with desirable pharmacological effects and subsequently purify them as a preliminary step towards achieving drugs which may be useful in curing some of the dreaded diseases of mankind.

Nature has blessed us with arsenal of plants with medicinal abilities, among the plants that have health benefits are Clerodendrum volubile. The plants belong to the family Lamiaceae (Verbenaceae), (Erukainure et al.,2010). Despite the fact that the genus Clerodendrum has gained attention of researchers for ample in vitro and in vivo studies, only few researchers have worked on isolation and identification of various chemical components and biological activities of the genus (Pallab et al., 2014) Clerodendrum volubile is an important species out of about 580 identified species found within the genus. This species is popularly known in South-South Nigeria due to its medicinal and food values. It is one of the leafy vegetables commonly consumed by the people. The plant is called marugbo, eweta, dagba and Obenetete by the Ikale people in Ondo state and Urhobo and Itsekiri tribes in Niger-Delta of Nigeria respectively. Due to its efficacy in management and treatment of numerous ailments, the leaves of Clerodendrum volubile have been referred to as "magic leaf."(Ochuko et al., 2014) Several medicinal claims attributed to this plant include antiinflammatory, anti-oxidant properties as well as its application in the treatment of arthritis, oedema, dropsy, swellings, gout and rheumatism. It is also used as pain-killers. (Fred-Jaiyesimi et al., 2012).

\section{MATERIALS AND METHOD}

\section{Study Location}

The Clenrodendrum volubile plants used for this study were obtained from Okitipupa a town in Ondo state, then the leaves were removed from the stalk and then spread and allowed to dry at room temperature for 21 days, after which they were grinded with electric blender into a powder and bottled in a sterile container before it was taken to the laboratory for analysis. Some of the Clenrodendrum volubile plant leaves were removed from the stalk of the plant and taken to the laboratory for analysis. All analysis was carried out in Ondo State University of Science and Technology (OSUSTECH) Laboratory Okitipupa.

\section{Preparation of Plant Extracts}

Sample 1

The leaves were removed from their stalks, thoroughly washed with tap water and rinsed with distilled water to remove sand and other impurities. The leaves were air-dried for twenty one (21) days. The dried leaves were subsequently ground into fine powder by using a commercial blender. The powdered samples were stored in a bottled before they were used. The plant materials $(10 \mathrm{~g})$ were extracted with $100 \mathrm{ml}$ of ethanol, $100 \mathrm{ml}$ of ordinary distilled water and $100 \mathrm{ml}$ of hot distilled water in which each was measured using a measuring cylinder and poured into sterile containers with proper labeling according to the names of the solvents. This same process was repeated using the following weight of plant materials $(20 \mathrm{~g}, 30 \mathrm{~g}, 40 \mathrm{~g}, 50 \mathrm{~g}, 60 \mathrm{~g})$ with each plant material being extracted with the same volume and concentration of ethanol, ordinary distilled water, and hot distilled water. The mixtures were homogenized and kept for $48 \mathrm{hrs}$ at room temperature. Each labeled mixture was then filtered using a sterile whattman filter paper after which the extract was obtained, to get a clearer extract.

\section{Sample 2}

Fresh leaves were removed from their stalks, thoroughly washed with tap water and rinsed with distilled water to remove sand and other impurities. The leaves were weighed for each concentration and then macerated before plant extract was prepared from the macerated leaves with $100 \mathrm{ml}$ of ethanol, $100 \mathrm{ml}$ of ordinary distilled water and $100 \mathrm{ml}$ of hot distilled water in which each was measured using a measuring cylinder and poured into sterile containers with proper labeling according to the names of the solvents.The mixtures were homogenized and kept for $48 \mathrm{hrs}$ at room temperature. Each labeled mixture was then filtered using a sterile muslin bag after which the extract was obtained, to get a clearer extract. This same process was repeated using the following weight of plant materials $(20 \mathrm{~g}, 30 \mathrm{~g}, 40 \mathrm{~g}, 50 \mathrm{~g}, 60 \mathrm{~g})$ with each plant material being extracted with the same volume and concentration of ethanol, ordinary distilled water, and hot distilled water.

\section{Antimicrobial Assay Of Plant Extract Against Selected Pathogen}

The different concentration of plant extract obtained from sample1 and sample 2 was used after 48 hours and 18plates of prepared agar containing 24 hours growth of the test organism was used, The organisms were taken after 24 hours and dissolve in saline water and compared against 0.5 macfarland standard before swab-stick was dipped into the solution and used to streak the surface of the prepared plates. 6plates for each plant extract of different concentration. Holes were bored into the prepared plates with a cork borer and the different concentration of plant extracts was dropped into the wells and then allowed to diffuse into the wells for 15 minutes before the plates were incubated at $37^{\circ} \mathrm{C}$ for $24 \mathrm{hrs}$. The plates were examined for zones of inhibition, which indicate the degree of susceptibility of the test organism. The antimicrobial activity of the various concentration of plant extract were measured with a metre rule and the result were recorded. 


\section{RESULTS}

TABLE1: Phytochemical Screening Analysis of Clenrodendrum volubile leaves

\begin{tabular}{|c|c|c|c|}
\hline $\begin{array}{c}\text { PHYTOCHEMICAL } \\
\text { COMPONENT }\end{array}$ & $\begin{array}{c}\text { ETHANOL } \\
\text { EXTRACT }\end{array}$ & $\begin{array}{c}\text { HOTWATER } \\
\text { EXTRACT }\end{array}$ & $\begin{array}{c}\text { COLDWATER } \\
\text { EXTRACT }\end{array}$ \\
\hline SAPONIN & $+\mathrm{ve}$ & $+\mathrm{ve}$ & $+\mathrm{ve}$ \\
\hline PHENOL & $+\mathrm{ve}$ & $+\mathrm{ve}$ & $+\mathrm{ve}$ \\
\hline FLAVONOIDS & $+\mathrm{ve}$ & $+\mathrm{ve}$ & $+\mathrm{ve}$ \\
\hline GLYCOSIDE & $+\mathrm{ve}$ & $-\mathrm{ve}$ & $+\mathrm{ve}$ \\
\hline $\begin{array}{c}\text { TRITERPENES } \\
\text { AND STEROID }\end{array}$ & $+\mathrm{ve}$ & $+\mathrm{ve}$ & $-\mathrm{ve}$ \\
\hline $\begin{array}{c}\text { PROTEIN AND } \\
\text { AMINO ACID }\end{array}$ & $-\mathrm{ve}$ & $+\mathrm{ve}$ & $+\mathrm{ve}$ \\
\hline
\end{tabular}

Keyword

\begin{tabular}{|c|c|}
\hline$+\mathrm{ve}$ & PRESENT \\
\hline$-\mathrm{ve}$ & ABSENT \\
\hline
\end{tabular}

TEST ORGANISM: salmonella enteritidis ATCC 1307

TABLE 2: Result of Salmonella enteritidis ATCC 1307 susceptibility to different concentration of extract

\begin{tabular}{|c|c|c|c|c|c|c|c|}
\hline \multirow{2}{*}{$\begin{array}{c}\text { PLANT } \\
\text { EXTRACTS }\end{array}$} & $\begin{array}{c}\text { PLANT } \\
\text { MATERIALS } \\
\text { USED }\end{array}$ & \multicolumn{5}{|c|}{ CONCENTRATION WITH ZONES } \\
\hline & & $10^{-1}$ & $\begin{array}{c}10^{-} \\
2^{-}\end{array}$ & $10^{-3}$ & $\begin{array}{c}10^{-} \\
4\end{array}$ & $10^{-5}$ & $10^{-6}$ \\
\hline \multirow{2}{*}{ ETHANOL } & fresh leaves & $11^{\mathrm{a}}$ & $13^{\mathrm{b}}$ & $14^{\mathrm{c}}$ & $14^{\mathrm{c}}$ & $13^{\mathrm{b}}$ & $13^{\mathrm{b}}$ \\
\cline { 2 - 8 } & Dry leaves & $12^{\mathrm{a}}$ & $13^{\mathrm{b}}$ & $14^{\mathrm{c}}$ & $14^{\mathrm{c}}$ & $11^{\mathrm{a}}$ & $12^{\mathrm{a}}$ \\
\hline \multirow{2}{*}{$\begin{array}{c}\text { HOT } \\
\text { WATER }\end{array}$} & fresh leaves & $10^{\mathrm{a}}$ & $10^{\mathrm{a}}$ & $14^{\mathrm{c}}$ & $14^{\mathrm{c}}$ & $11^{\mathrm{b}}$ & $12^{\mathrm{c}}$ \\
\cline { 2 - 8 } & Dry leaves & $10^{\mathrm{a}}$ & $10^{\mathrm{a}}$ & $11^{\mathrm{b}}$ & $11^{\mathrm{b}}$ & $11^{\mathrm{b}}$ & $12^{\mathrm{c}}$ \\
\hline $\begin{array}{c}\text { COLD } \\
\text { WATER }\end{array}$ & fresh leaves & $9^{\mathrm{a}}$ & $10^{\mathrm{b}}$ & $10^{\mathrm{b}}$ & $12^{\mathrm{c}}$ & $12^{\mathrm{c}}$ & $13^{\mathrm{c}}$ \\
\cline { 2 - 8 } & Dry leaves & $8^{\mathrm{a}}$ & $10^{\mathrm{b}}$ & $11^{\mathrm{b}}$ & $12^{\mathrm{c}}$ & $12^{\mathrm{c}}$ & $12^{\mathrm{c}}$ \\
\hline
\end{tabular}

a, b, c Means with different superscripts in a row are significantly different $(\mathrm{P}<0.05)$.

TEST ORGANISM: shigella flexnerium ATCC 120222

TABLE 3: Result of shigella flexnerium ATCC120222 susceptibility to different concentration of extract

\begin{tabular}{|c|c|c|c|c|c|c|c|}
\hline \multirow[t]{2}{*}{$\begin{array}{c}\text { PLANT } \\
\text { EXTRACTS }\end{array}$} & \multirow[t]{2}{*}{$\begin{array}{c}\text { PLANT } \\
\text { MATERIALS } \\
\text { USED } \\
\end{array}$} & \multicolumn{6}{|c|}{$\begin{array}{l}\text { CONCENTRATION WITH ZONES } \\
\text { OF INHIBITION }(\mathrm{mm})\end{array}$} \\
\hline & & $10^{-1}$ & $10^{-2}$ & $10^{-3}$ & $10^{-4}$ & $10^{-5}$ & $10^{-6}$ \\
\hline \multirow{2}{*}{ ETHANOL } & fresh leaves & $10^{\mathrm{a}}$ & $12^{\mathrm{b}}$ & $13^{\mathrm{bc}}$ & $13^{\mathrm{bc}}$ & $12^{\mathrm{b}}$ & $20^{c}$ \\
\hline & Dry leaves & $7^{\mathrm{a}}$ & $8^{\mathrm{a}}$ & $10^{\mathrm{b}}$ & $12^{\mathrm{c}}$ & $12^{\mathrm{c}}$ & $10^{\mathrm{b}}$ \\
\hline \multirow{2}{*}{$\begin{array}{c}\text { HOT } \\
\text { WATER }\end{array}$} & fresh leaves & $7^{\mathrm{a}}$ & $8^{\mathrm{a}}$ & $8^{\mathrm{a}}$ & $10^{\mathrm{b}}$ & $11^{\mathrm{b}}$ & $13^{\mathrm{c}}$ \\
\hline & Dry leaves & $7^{\mathrm{a}}$ & $7^{\mathrm{a}}$ & $11^{\mathrm{b}}$ & $14^{\mathrm{c}}$ & $20^{c}$ & $10^{\mathrm{b}}$ \\
\hline \multirow{2}{*}{$\begin{array}{l}\text { COLD } \\
\text { WATER }\end{array}$} & fresh leaves & $10^{\mathrm{a}}$ & $10^{\mathrm{a}}$ & $10^{\mathrm{a}}$ & $11^{\mathrm{b}}$ & $12^{\mathrm{c}}$ & $12^{\mathrm{c}}$ \\
\hline & Dry leaves & $10^{\mathrm{a}}$ & $12^{\mathrm{bc}}$ & $12^{\mathrm{bc}}$ & $14^{\mathrm{c}}$ & $11^{\mathrm{b}}$ & $11^{\mathrm{b}}$ \\
\hline
\end{tabular}

a, b, c Means with different superscripts in a row are significantly different $(\mathrm{P}<0.05)$.

\section{TEST ORGANISM: Escherichia coli}

TABLE 4: Result of Escherichia coli susceptibility to different concentration of extract

\begin{tabular}{|c|c|c|c|c|c|c|c|}
\hline $\begin{array}{c}\text { PLANT } \\
\text { EXTRACTS }\end{array}$ & $\begin{array}{c}\text { PLANT } \\
\text { MATERIALS } \\
\text { USED }\end{array}$ & \multicolumn{5}{|c|}{ CONCENTRATION WITH ZONES } \\
\hline & & $10^{-1}$ & $\begin{array}{c}10^{-} \\
2^{-3}\end{array}$ & $10^{-3}$ & $10^{-4}$ & $10^{-5}$ & $10^{-6}$ \\
\hline \multirow{2}{*}{ ETHANOL } & fresh leaves & $11^{\mathrm{a}}$ & $11^{\mathrm{a}}$ & $13^{\mathrm{b}}$ & $14^{\mathrm{c}}$ & $13^{\mathrm{b}}$ & $15^{\mathrm{c}}$ \\
\cline { 2 - 8 } & Dry leaves & $11^{\mathrm{a}}$ & $12^{\mathrm{a}}$ & $13^{\mathrm{b}}$ & $13^{\mathrm{b}}$ & $18^{\mathrm{c}}$ & $20^{\mathrm{c}}$ \\
\hline \multirow{2}{*}{$\begin{array}{c}\text { HOT } \\
\text { WATER }\end{array}$} & fresh leaves & $8^{\mathrm{a}}$ & $8^{\mathrm{a}}$ & $10^{\mathrm{b}}$ & $11^{\mathrm{bc}}$ & $12^{\mathrm{c}}$ & $12^{\mathrm{c}}$ \\
\cline { 2 - 8 } & Dry leaves & $8^{\mathrm{a}}$ & $9^{\mathrm{a}}$ & $10^{\mathrm{b}}$ & $10^{\mathrm{b}}$ & $11^{\mathrm{c}}$ & $11^{\mathrm{c}}$ \\
\hline \multirow{2}{*}{$\begin{array}{c}\text { COLD } \\
\text { WATER }\end{array}$} & fresh leaves & $7^{\mathrm{a}}$ & $9^{\mathrm{a}}$ & $9^{\mathrm{a}}$ & $10^{\mathrm{b}}$ & $10^{\mathrm{b}}$ & $11^{\mathrm{c}}$ \\
\cline { 2 - 8 } & Dry leaves & $7^{\mathrm{a}}$ & $8^{\mathrm{a}}$ & $8^{\mathrm{a}}$ & $10^{\mathrm{b}}$ & $10^{\mathrm{b}}$ & $11^{\mathrm{c}}$ \\
\hline
\end{tabular}

${ }^{\mathrm{a}, \mathrm{b}, \mathrm{c}}$ Means with different superscripts in a row are significantly different $(\mathrm{P}<0.05)$.

\section{DISCUSSION}

Medicinal plants are widely used in African communities to treat different types of bacterial diseases (Sofowora, 1993). Phytochemical screening of the plant extracts revealed the presence of one or more of the following phytochemical components; saponin, phenols, flavonoids, glycosides, triterpenes and steroids, proteins and amino acid. Clerodendrum commonly used by indigenes in south western communities of Nigeria to treat different sicknesses. The presence of some phytochemicals in the plant extracts studied is a function of their antimicrobial activities against the test pathogen as they play important roles in bioactivity of medicinal plants. The leaf part of the plant was chosen for the research because reports have claimed that biologically active components in medicinal plants are usually concentrated in their leaves.

2019)

(Francisco et.al.,

All of the phytochemical components are present in the ethanol extract except proteins and amino acid, this might be responsible for its extract being the most active and potent against the tested pathogens. Glycosides was not observed in hot water extract and triterpenes and steroids are not present in cold water extracts, this might be the reason why cold water extracts are the least active of the three extracts because terpenoids (triterpenes) have antimicrobial and anti-diarrhoeal properties which helps in membrane disruption and it also Inhibits release of autocoids and prostaglandins. Bioactive compounds found in clenrodendrum volubile are known to play a vital role in promoting health, their presence imply they could be utilized to improve health. Saponins are antidiarrhoeal, anticancer, anthelmintic, they Inhibit histamine release in-vitro and Possesses membrane permeability properties which leads to disintegration of teguments. Steroids are anti-diarrhoeal and they enhance intestinal absorption of $\mathrm{Na}^{+}$and water. 
The antibacterial activity of Clerodendrum volubile was ascertained when used against Salmonella enteritidis, Shigella flexnerium and Escherichia coli. Clerodendrum volubile exhibited diverse antimicrobial activity at varied concentrations. The zones of inhibition produced by these extract against the pathogenic bacteria is shown in table 2,3 and 4 respectively. The ethanol extract was most active against all the tested pathogens when compared with other extracts used. Highest zone of inhibition (20mm) was produced by ethanol extract of against Escherichia coli and Shigella flexnerium. It was clear from this study that solvent extraction affected the degree of antibacterial activity of the extracts this is in agreement with the work of (Odikamnoro et al., 2015; Chang et.al., 2018). However, the average zones of inhibitions observed against these pathogens ranged from (8 to $13 \mathrm{~mm}$ ) for Salmonella enteritidis ATCC 1307, from (7 to 20mm) for Shigella flexnerium ATCC120222, from (7 to $20 \mathrm{~mm}$ ) for Escherichia coli. Although, the low values recorded for the plant extracts may be attributed to the fact that the extracts being in crude form, contain very small amounts of bioactive compounds. At the same time, several workers have reported bioactivity of crude extracts of medicinal plants within such range of diameter of zone of inhibitions (Olukoya et al., 1993; Ilori et al., 1996; Ogbeche et al.,1997; Akinyemi et al.,2005). Our present study conformed to these previous findings.

The values of the different zones of inhibition that differs significantly $(\mathrm{P}<0.05)$ are represented by different subscript. The zones of inhibition increases across the row but decreases at some point in the rows for salmonella and shigella as shown in table 2 and 3 . The pathogens are generally susceptible as the concentration increases. Cold water generally has the lowest zones of inhibition; it might be because it was not able to dissolve organic components present in the plant leaves readily.

In table 2, Ethanol extract of fresh leaves exerts slightly higher activity than both hot water and cold water extract of fresh leaves, zones of inhibition also increase across the column. As concentration increases, the zones of inhibition increases until it reaches $10^{-4}$ concentration $(14 \mathrm{~mm})$ which is the highest zone of inhibition, the zones of inhibition then decrease to $(13 \mathrm{~mm})$ which might indicate the minimum inhibitory concentration is $10^{-4}$ concentration. Zones of inhibition of ethanol extract of dry leaves also increases across the column with the highest at $(14 \mathrm{~mm})$ and later decreases as that of fresh leaves. Ethanol extract of fresh leaves exert more susceptibility on Salmonella enteritidis ATCC 1307 across the column but they have the same highest zone of inhibition. Across the row ethanol, hot water and cold water extract are significantly different from each other. This is in agreement with the results of Dieu-Hien et.al., 2019, Otang, 2016 that got a higher extraction yield in methanolic extract, distilled water extract, and ethanolic extract compared to chloroform, dichloromethane, and acetone extracts respectively, indicating that the extraction efficiency favors the highly polar solvents.
For hot water fresh leaves extract, the highest zone of inhibition is the $10^{-4}$ concentration $(14 \mathrm{~mm})$ and the zone of inhibition increases along the column before it started decreasing to $(12 \mathrm{~mm})$ for $10^{-6}$ concentration which might be because the MIC is $10^{-4}$ concentration. Zones of inhibition for hot water dry leaves extract increases along the column with the highest concentration $\left(10^{-6}\right)$ producing the largest zone of inhibition $(12 \mathrm{~mm})$, the varied concentration producing different zones of inhibition are significantly different from each other which shows the degree of susceptibility of the test pathogens. Cold water extract produces the lowest zone of inhibition $(9 \mathrm{~mm})$ in table 2, and as the concentration increases, the zone of inhibition also increases, with the highest concentration $\left(10^{-6}\right)$ having the highest zone of inhibition $(13 \mathrm{~mm})$ for fresh leaves and $(12 \mathrm{~mm})$ for dry leaves. Cold water fresh leaves extract exerts more susceptibility and produces more zones of inhibition than cold water dry leaves extract on Salmonella enteritidis ATCC 1307.

For table 3, ethanol extract of fresh leaves produces zones of inhibition which increases with the concentration, at $10^{-3}$ and $10^{-4}$ concentration, zones of inhibition are the same $(13 \mathrm{~mm})$ which indicates that they are not significantly different from each other, the $10^{-6}$ concentration produces the highest zone of inhibition $(20 \mathrm{~mm})$ which shows the effect of concentration on the tested pathogens, ethanol extract of fresh leaves produces more susceptibility $(20 \mathrm{~mm})$ than that of the dry leaves $(12 \mathrm{~mm})$ which might be because fresh leaves are more bioavailable than the dry leaves when ethanol is used as extracting agent. Hot water dry leaves extract have the highest zone of inhibition (20mm) which increases across the column and later decreases for the $10^{-6}$ concentration which might be because the minimum inhibitory concentration is the $10^{-5}$ concentration while the highest zone of inhibition for hot water fresh leaves extract also increases along the column with the highest zone of inhibition $(13 \mathrm{~mm})$ produced by the highest concentration $\left(10^{-6}\right.$ concentration), for table 3 , hot water has the lowest zone of inhibition $(7 \mathrm{~mm})$ which might be because the bioactive components are destroyed by the hot water. For cold water fresh leaves extract, zones of inhibition increases across the column with the highest zone of inhibition $(14 \mathrm{~mm})$ produced by dry leaves which might indicate that it is more bio-available than fresh leaves extract. Across the row, dry leaves extract of cold water exerts more susceptibility than fresh leaves when used against Shigella flexnerium ATCC 12222. For $10^{-2}$ and $10^{-3}$ concentration with the same zone of inhibition $(12 \mathrm{~mm})$ indicates that they are not significantly different from each other.

For table 4, ethanol extract of both fresh and dry leaves produces zones of inhibition which increases across the column as the concentration increases, dry leaves extract produces the highest zones of inhibition (20mm). Ethanol extract in table 4, exerts more activity than hot water and cold water, zones of inhibition produced by ethanol is significantly different from those of hot water and cold water. The highest zone of inhibition $(12 \mathrm{~mm})$ is produced by the highest 
concentration for hot water, cold water produces the lowest zones of inhibition $(7 \mathrm{~mm})$, both cold water and hot water produces zones of inhibition that increases across the column with increase in concentration.

\section{CONCLUSION}

Several hundreds of plant extracts and herbs have been tested for in vitro antibacterial activity with few controlled clinical trials published. The clinical efficacy of herbal medicines are being demonstrated beyond doubt. This area seems to merit further study through rigorous clinical trials.

\section{REFERENCES}

[1] Akinyemi, K. O., Oladapo, O., Okwara, C. E., Ibe, C. C and Fasure, A. K., (2005). Screening of crude extracts of some medicinal plants used in South West Nigerian Unorthodox medicine for anti-methicilin resistant

[2] Bessada SMF, Barreira JCM, Oliveira MBPP (2015). Asteraceae species with most prominent bioactivity and their potential applications: A review. Ind Crops Prod. Elsevier B.V.; 2015; 76: 604-615. https://doi.org/ 10.1016/j.indcrop.2015.07.073 7. Borges $\mathrm{CC}$, Matos TF, Moreira J, R

[3] Chang, F.-R. Li, P.-S. Huang Liu R. (2018), "Bioactive phenolic components from the twigs of Atalantia buxifolia," Journal of Natural Products, vol. 81, no. 7, pp. 1534-1539.

[4] Chiavari-Frederico MO, Barbosa LN, Carvalho dos Santos I, Ratti da Silva G, Fernandes de Castro A, de Campos Bortolucci W, et al. (2020) Antimicrobial activity of Asteraceae species against bacterial pathogens isolated from postmenopausal women. PLoS ONE 15(1): $\quad$ e0227023. org/10.1371/journal.pone.0227023

[5] Dieu-Hien Truong, Dinh Hieu Nguyen, Nhat Thuy Anh Ta, Anh Vo Bui, Tuong Ha Do, and Hoang Chinh Nguyen (2019). Evaluation of the Use of Different Solvents for Phytochemical Constituents, Antioxidants, and In Vitro Anti-Inflammatory Activities of Severinia buxifolia. Journal of food quality, Volume 2019|Article ID 8178294 | 9 pages | https://doi.org/10.1155/2019/8178294

[6] Erukainure O. L., Oke O.V., Owolabi F.O., Adenekan S. O., (2010) Antioxidant nutrient properties and antioxidant activities of obenetete (Clerodendrum volubile), a non-conventional leafy vegetable consumed in Nigeria. African J. Food, Agric, and Nutr Dev; 10(10):4156-4167.

[7] Farnsworth (1988). Screening plants for new drugs. Biodiversity. Washington (DC): National Academies Press (US); 1988. https://www.ncbi.nlm.nih.gov/books/NBK219315/

[8] Francisco J. B; Jose E.M; Jose E; Frigola A (2014). Bioactive Components from Leaf Vegetable Products. Studies in Natural Products Chemistry 41:321-346. DOI: 10.1016/B978-0-444-63294-4.00011-5.

[9] Fred-Jaiyesimi A, Adekoya Y. (2012) Pharmacognostic studies and anti-inflammatory activities of Clerodendrum volubile $\mathrm{P}$ Beauv Leaf. Int J Phytomed; 4: 414-418

[10] Ilori, M. O, Shiteolu O. A, Omonigbehin E. A and Adeneye, A. A., (1996). Anti- diarrhoeal activity of Ocimum gratissimum (Lamiaceae). J. Diarrhoeal Dis. Res. 14: 54-58.

[11] Jain, S., Jacob, M., Walker, L.(2016). Screening North American plant extracts in vitro against Trypanosoma brucei for discovery of new antitrypanosomal drug leads. BMC Complement Altern Med (16), 131 . https://doi.org/10.1186/s12906-016-1122-0

[12] Mamedov, N., (2012) Medicinal plants studies: history, challenges and prospective. Med Aromat Plants. 1:e133. Doi:10.4172/2167$0412.1000 \mathrm{e} 133$

[13] Ochuko, L. E., Osaretin, A. T., Ebuehi I. M., Choudhary A. A., Rahman M. H., Shahida P., Aliyu M., Gloria N. E., (2014) Iridoid Glycoside from the Leaves of Clerodendrum volubile Beauv. Shows Potent Antioxidant Activity against Oxidative Stress in Rat
Brain and Hepatic Tissues. Journal of Dietary Supplements; 11(1):19-29

[14] Odikamnoro, O. O., Uhuo, C. A., Ikeh, I. M., Ogiji, E. D., Akpam, L. J., Ibiam, G. A., Azi, S. O. and Okoh, N. F. (2015). Antibacterial activities of Salmonella typhi isolates in Abakaliki, Ebonyi State, Nigeria: Improvement to herbal medicine. 7(2): 14 18

[15] Ogbeche, A. K., Ajayi, G. O. and Onyeneta, P., (1997). Antibacterial activities of the leaf extract of Ageratum conyzoides Nig. Qt. J. Hosp. Med., 7:397-399.

[16] Olukoya, D.K., Idika N. and Odugbemi T., (1993). Antimicrobial activity of some medicinal plants from Nigeria. $J$. Ethnopharmacol. 39: 69-72.

[17] Otang W, Afolayan A. Antimicrobial and antioxidant efficacy of Citrus limon L. peel extracts used for skin diseases by Xhosa tribe of Amathole District, Eastern Cape, South Africa. S Afr J Bot. 2016;102:46-9.

[18] Pallab, K., Arvind K. G., Abhaya P. D., Arnab S. (2014) Antioxidant and pharmaceutical potential of Clerodendrum Leaves: An overview. Int. J. Green Pharm.; 3:1-7

[19] Rotimi Larayetan, Zacchaeus S. Ololade, Oluranti O. Ogunmola, Ayodele Ladokun (2019) "Phytochemical Constituents, Antioxidant, Cytotoxicity, Antimicrobial, Antitrypanosomal, and Antimalarial Potentials of the Crude Extracts of Callistemon citrinus", Evidence-Based Complementary and Alternative Medicine, vol. 2019, Article ID 5410923, 14 pages. https://doi.org/10.1155/2019/5410923

[20] Ryszard K (1998). Green Fibres and Their Potential in Diversified Applications. http://www.fao.org/3/y1873e/y1873e0b.htm

[21] Sofowora, A. (1993). Medicinal Plants and Traditional Medicines in Africa. Chic Hester John, Willey \& Sons N. Y. p. 256.

[22] WHO. (2002). Traditional medicine strategy 2002-2005. Geneva, Switzerland.

[23] WHO. (2011). The world medicines situation. Traditional Medicines: Global Situation Issues and Challenges. WHO, Geneva, Switzerland.

[24] Zaria Gorvett (2020). The medications that change who we are. https://www.bbc.com/future/article/20200108-the-medicationsthat-change-who-we-are 